Old Dominion University

ODU Digital Commons

History Faculty Publications

History

7-2019

\title{
Practices of Intellectual Labor in the Republic of Letters: Leibniz and Edward Bernard on Language and European Origins
}

Michael C. Carhart

Old Dominion University, mcarhart@odu.edu

Follow this and additional works at: https://digitalcommons.odu.edu/history_fac_pubs

Part of the European History Commons, and the European Languages and Societies Commons

\section{Repository Citation}

Carhart, Michael C., "Practices of Intellectual Labor in the Republic of Letters: Leibniz and Edward Bernard on Language and European Origins" (2019). History Faculty Publications. 43.

https://digitalcommons.odu.edu/history_fac_pubs/43

\section{Original Publication Citation}

Carhart, M. C. (2019). Practices of intellectual labor in the Republic of Letters: Leibniz and Edward Bernard on language and European origins. Journal of the History of Ideas, 80(3), 365-386. doi:10.1353/jhi.2019.0023

This Article is brought to you for free and open access by the History at ODU Digital Commons. It has been accepted for inclusion in History Faculty Publications by an authorized administrator of ODU Digital Commons. For more information, please contact digitalcommons@odu.edu. 


\title{
Practices of Intellectual Labor in the Republic of Letters: Leibniz and Edward Bernard on Language and European Origins
}

\author{
Michael C. Carhart
}

While reading Wilhelm Ernst Tentzel's Monatliche Unterredungen in 1691, Leibniz came across a discussion of Edward Bernard's Etymologicon Britannicum. Published in 1689 as an appendix to George Hickes's grammar of Anglo-Saxon and Gothic, Bernard's glossary comprised some eight hundred terms from the British Isles that shared cognates in the Persian and Armenian languages of central and western Asia as well as several others of eastern and western Europe. It was known that in the historical era Britain was invaded by several waves of people-Gauls, Angles and Saxons, the Norse, the post-Norse Normans. But who were the indigenous people of Britain? Bernard's etymological glossary offered linguistic evidence of the prehistoric origins of the British far away on the Slavic/Armenian/Persian frontier around the Caspian Sea. The convergence of now-diverse and widely distributed languages suggested a common origin of the human race, or if not the origin of all humankind then at least of the nations of Europe. Bernard concluded the Etymologicon Britannicum with a slogan excerpted from Noah's blessing in Genesis 9, "God shall enlarge Japheth."

\footnotetext{
${ }^{1}$ Edward Bernard, Etymologicon Britannicum, in George Hickes, Institutiones Grammaticae Anglo-Saxonicae et Moeso-Gothicae (Oxford: Sheldon Theatre, 1689), sig. Uu1v. See Richard L. Harris, ed., A Chorus of Grammars: The Correspondence of George Hickes and his Collaborators on the Thesaurus linguarum septentrionalium (Toronto: Pontifical Institute of Medieval Studies, 1992), esp. 24-27. For Hickes as an
} 
Only months earlier Leibniz had articulated a project that would establish the prehistoric origins and migrations of the people of Lower Saxony (and of Germanic Europe generally) by a method of comparative vocabulary analysis. This project was to be a second preliminary discourse to Origines Guelphicae, the genealogy of the dynasty of Braunschweig-Lüneburg that he had been assigned in 1685 and that would occupy the bulk of his scholarly efforts for the rest of his life (d. 1716). By 1691 Leibniz had been back from his Italian grand tour for a year, and during that winter and spring he had devised two preliminary discourses for the genealogy, one describing the land where the Guelphs ruled, the other describing the people. ${ }^{2}$ When Leibniz came upon Tentzel's discussion of Bernard's hypothesis of the Asiatic origins of the European nations, he was keen to see the data on which that hypothesis was based.

The quest for human and national origins was more than mere intellectual curiosity. ${ }^{3}$ Leibniz's linguistic project, as a second preliminary discourse to Origines Guelphicae, was about legitimacy. Origines Guelphicae itself-the genealogy of the dynasty of Braunschweig-Lüneburg-was obviously about political legitimacy. The genealogy's immediate purpose was to justify the elevation of the Hanoverian house to the rank of elector, the highest in the Holy Roman Empire. In the aftermath of the Thirty Years' War, the house of Braunschweig had emerged as one of the most powerful dynasties of northern Germany, and with some territorial wrangling much of that power had been consolidated in the person of the duke of Lüneburg. ${ }^{4}$ But power could be fleeting. In order to demonstrate the ancient dignity of the dynasty, Leibniz traced the early origins of the house to an eleventh-century merger of a noble house in lower Bavaria with the ancient Italian house of Este, and the rise of that house of Welf (Guelph) to the rank of Holy Roman Emperor in the person of Otto IV. Leibniz intended to bring his medieval genealogy down to the year 1235 , when the duchy of

advocate of the Nordic origins of the Germanic languages, see Alfred Hiatt, "Hickes Against Mabillon in the Republic of Letters," Journal of the History of Ideas 70 (2009): 351-73.

${ }^{2}$ Michael C. Carhart, Leibniz Discovers Asia: Social Networking in the Republic of Letters (Baltimore: Johns Hopkins University Press, 2019), 11-30; Maria Rosa Antognazza, Leibniz: An Intellectual Biography (New York: Cambridge University Press, 2009), 324-30.

${ }^{3}$ John Considine, Small Dictionaries and Curiosity: Lexicography and Fieldwork in PostMedieval Europe (New York: Oxford University Press, 2017).

${ }^{4}$ Georg Schnath, Geschichte Hannovers im Zeitalter der neunten Kur und der englischen Sukzession, 1674-1714, 5 vols. (Hildesheim: Lax, 1938-82); Peter H. Wilson, Heart of Europe: A History of the Holy Roman Empire (Cambridge, MA: Belknap Press of Harvard University Press, 2016). 
Braunschweig-Lüneburg was formally incorporated by Frederick II and the Welfs were legitimized as its princes by their Hohenstaufen rivals.

The second preliminary discourse, Migrationes Gentium, was also about legitimacy, not so much political as cultural or national. The people governed by the house of Welf, the Saxons of lower Germany, existed not only in the core domain of Hanover and its territories but were broadly distributed around the North Sea basin: Low-Germanic-speaking AngloSaxons in England, Danes and Swedes in Scandinavia, Icelanders whose language was demonstrably related to Low Germanic, the Dutch, and even the Franks of France all shared a common origin. That is to say, in an age when vernacular German was first being promoted as a worthy literary language (long before nineteenth-century nationalism), ${ }^{5}$ Leibniz claimed for Lower Saxony a cultural legitimacy that underlay some of Europe's most powerful lands, politically, economically, and intellectually.

Scholars had long looked to Asia as the original homeland of the nations that presently occupied Europe. Some read Genesis 10 as suggesting that Noah's son Japheth had departed Ararat and Gordyaeus for the north (possibly before the Babel episode in Genesis 11) and that Europeans were descended from them. ${ }^{6}$ But the biblical approach was by no means universal. Others (including Leibniz) looked for non-biblical evidence, like cognate terms in historical languages, that many nations-from the Ganges to Persia to the steppes and the West-were descended from a common origin and might formerly have spoken a common proto-language. ${ }^{7}$ Edward Bernard was of this latter, non-biblical set too, despite his invocation of Japheth in the last line of the Etymologicon Britannicum.

In advancing a hypothesis of the "Scythian" origins of the Germanic nation, Leibniz was challenging Swedish scholarship, which for a century and a half had been building a case that the ancestors of the Germanic

\footnotetext{
${ }^{5}$ Daniel Georg Morhof, Unterricht von der teutschen Sprache und Poesie (Kiel: Reumann, 1682).

${ }^{6}$ Arno Borst, Der Turmbau von Babel, 4 vols. in 6 parts (Stuttgart: Hirsemann, 195763); Maurice Olender, "Europe, Or How to Escape Babel," History and Theory 33 (1994): 5-25; Daniel Droixhe, Souvenirs de Babel: La reconstruction de l'histoire des langues de la Renaissance aux Lumières (Brussels: Académie royale de langue et de littérature français de Belgique, 2007).

${ }^{7}$ Stephan Waldhoff, "Leibniz und der Plausibilitätsverlust der biblischen Völkergenealogie," in Leibniz und das Judentum, ed. Daniel J. Cook, Hartmut Rudolph, and Christoph Schulte, Studia Leibnitiana, Sonderheft 34 (Stuttgart: Steiner, 2008), 155-81; George J. Metcalf, On Language Diversity and Relationship from Bibliander to Adelung, ed. Toon Van Hal and Raf Van Rooy (Philadelphia: John Benjamins, 2013); Han F. Vermeulen, Before Boas: The Genesis of Ethnography and Ethnology in the German Enlightenment (Lincoln: University of Nebraska Press, 2015), 72-81.
} 
nations were the Goths, and that the Goths had originated in Sweden, and, moreover, that the direct descendants of the Goths were still there. ${ }^{8}$ Now in Tentzel's Monatliche Unterredungen, Leibniz learned that Bernard had evidence that, although geographically speaking the Germanic homeland was indeed in Asia or the Caucasus, in linguistic terms Germanic was descended from Slavic. Leibniz needed to see the evidence on which Bernard based his assertion.

This article addresses both the content of historical linguistics itself and also how literary republicans did their work: that is, how scholarly communication was established, maintained, and severed. I am particularly interested in how Leibniz's intentions changed over time and especially how they changed in response to the knowledge that his literary friends sent him. In this case study, those correspondents can be grouped into three clusters: Tentzel, Hiob Ludolf, and Christian Franz Paullini, who were themselves centered around the Monatliche Unterredungen and a Collegium Imperiale Historicum that they had formed together; Henri Justel in London and Paul Pellisson-Fontanier in Paris; and Edward Bernard himself. It will be seen that Leibniz advanced the discussion not through direct assertions or claims about languages but rather through questions. These questions were intended to entice the correspondent to reply, and they offered a variety of topics (or approaches to a topic) to choose from. Leibniz placed himself in the position of a debtor to whom the recipient could become a literary creditor by doing a favor of supplying Leibniz with the knowledge that he sought.

\section{TENTZEL AND LUDOLF}

Leibniz first became aware of Bernard's Etymologicon Britannicum through the Monatliche Unterredungen (1690-98), a monthly journal of scholarly

\footnotetext{
${ }^{8}$ Olof Verelius, Index Linguae Veteris Scytho-Scandicae sive Gothicae, ed. Olof Rudbeck (Uppsala: n.p., 1691); Gunnar Eriksson, The Atlantic Vision: Olaus Rudbeck and Baroque Science (Canton, MA: Science History, 1994); Kurt Johannesson, The Renaissance of the Goths in Sixteenth-Century Sweden: Johannes and Olaus Magnus as Politicians and Historians (Berkeley: University of California Press, 1991); Kristoffer Neville, "Gothicism and Early Modern Historical Ethnography," Journal of the History of Ideas 70 (2009): 213-34; Annie Burman, "Language Comparison Before Comparative Linguistics: Theories of Language Change and Classification in Olof Rudbeck's Atlantica," in Apotheosis of the North: The Swedish Appropriation of Classical Antiquity Around the Baltic Sea and Beyond (1650-1800), ed. Bernd Roling, Bernhard Schirg, and Stefan Heinrich Bauhaus (Berlin: De Gruyter, 2017), 77-94.
} 
news written by Tentzel, librarian of the princely court at Gotha in north central Germany. Tentzel entertained actual discussions of recent publications broadly related to Germanic antiquities, and these discussions he fictionalized as extended dialogues whose characters agreed on many points but politely disagreed on others. In October 1691 Leibniz was reading through back issues of the journal when he came upon a private letter from Bernard to Hiob Ludolf that Tentzel had published. Ludolf, a scholar of Oriental languages (particularly the Amharic language of Ethiopia), carried on a correspondence with his fellow Orientalist at Oxford, Bernard. When Bernard had his Etymologicon Britannicum printed, he sent a copy of the Hickes volume to which it was appended along with a cover letter to Ludolf at Frankfurt. Ludolf made a copy of the cover letter and sent it to Gotha, where Tentzel published it in the July 1691 issue of Monatliche Unterredungen.

"I look forward to hearing what you think about our Etymologicon Britannicum," Bernard had written to Ludolf. "For there I indicated the source and first seats of all the Dialects of Europe, except for Latin. Very broadly speaking, all rivers eventually lead to Russian and Slavic regions." 9 That is to say, Bernard indicated a geographical homeland of the nations of Europe somewhere in the Tartaric margins of the growing empire of Muscovy-Ukraine, the Black Sea, the Caspian Sea, or the mountains between them. In the fictionalized discussion of Bernard's letter that Tentzel published, although Tentzel's circle rejected Bernard's thesis of Slavic and Armenian origins per se, nevertheless they were much taken with the idea of a northern nation that originated in the mountains of Ararat or Gordyaeus and subsequently spread both east and west to occupy both Asia and Europe. ${ }^{10}$

In August 1691, when Ludolf travelled to Gotha and brought Hickes's Anglo-Saxon Grammar, Tentzel saw more precisely what Bernard proposed: not merely a geographical origin of the languages of Europe but a linguistic origin too. "The Russian, Slavic, Persian, and Armenian Origins of English and British Words" was Bernard's subtitle and, functionally, also his thesis statement. Bernard's Etymologicon Britannicum was a glossary of English terms annotated with cognates in Slavic (Russian, Slavonic, Polish, Dalmatian and Croatian, Bohemian and Lusatian), Celtic (Breton, Armorican, Irish [Hibernian]), Persian, Armenian, Gothic, as well as Hungarian,

\footnotetext{
${ }^{9}$ Bernard to Hiob Ludolf, Oxford, 25 December 1690, OS (4 January 1691, NS), in Wilhelm Ernst Tentzel, Monatliche Unterredungen 3 (July 1691): 579-81.

${ }^{10}$ Tentzel, Monatliche Unterredungen 3 (September 1691): 761.
} 
Epirotic [Albanian], and Cantabrian [Basque]. Tentzel reprinted the first couple of pages to show what Bernard's Etymologicon Britannicum looked like.

It was a mere list of equivalent terms, and Bernard offered no narrative analysis. But in a prefatory letter that was printed in the Hickes volume and that Leibniz read when Tentzel reprinted it, Bernard explained what his compilation implied: "That the Saxons, from which most of our people come, and also the Icelanders, Danes, and Swedes (or by a more ancient and general name, the Goths), as well as almost all of the peoples of Germany were descended from the Russians and Slavs, which nation and language occupied the western world." ${ }^{11}$ Bernard was impressed by the affinity of languages across the temperate zone of Europe and western and central Asia. He reasoned that, following the confusion of languages at Babel, some of the Japhetic tribes scattered north toward the Caucasus, while others settled in Europe.

Tentzel rejected Bernard's hypothesis. First, Bernard's comparative methodology was not entirely new, Tentzel pointed out, but seemed to be drawn from Philippus Cluverius's Germania Antiqua (1616) and Matthaeus Praetorius's Orbis Gothicus (1688). ${ }^{12}$ Second, Bernard would have been quickly disabused of his Slavic-origin hypothesis had he read Georgius Hornius's preface to Marcus Zuerius Boxhorn's Origin of the Gauls and Daniel Georg Morhof's treatise on German poetics. ${ }^{13}$ Bernard's data set was far from exhaustive, Tentzel complained, a mere sampling that filled only four press sheets. It would take a native German speaker who had studied comparative languages to trace the etymological relationships between Germanic and the Orient, Tentzel wrote. Bernard was no better grounded in the German language than the Swede Olaf Rudbeck.

Nevertheless Bernard's hypothesis did raise some interesting questions about the relationships between the languages of Europe and western Asia. Tentzel's fictitious interlocutor "Leonhard" took ancient Germanic and Gothic to be the same language, and this Germano-Gothic (including

\footnotetext{
${ }^{11}$ Bernard to Hickes, Oxford, 15 May 1689, OS (25 May 1689, NS), in Bernard, Etymologicon Britannicum, in George Hickes, Institutiones Grammaticae; reprinted in Tentzel, Monatliche Unterredungen 3 (September 1691): 739-41.

${ }_{12}$ Philippus Cluverius, Germania antiqua libri tres (Leiden: Elzevir, 1616); Matthaeus Praetorius, Orbis Gothicus: Id est, Historica narratio, omnium fere Gothici nominis populorum origines, sedes, linguas, regimen, reges, mores ritus varios, conversionem ad fidem etc. (Oliva [Gdańsk]: Monasterium Olivensis, 1688).

${ }^{13}$ Georgius Hornius, "Ad lectorem," in Marcus Zuerius Boxhorn, Originum Gallicarum Liber (Amsterdam: Jansson, 1654), n.p.; Morhof, Unterricht von der Teutschen Sprache und Poesie.
} 


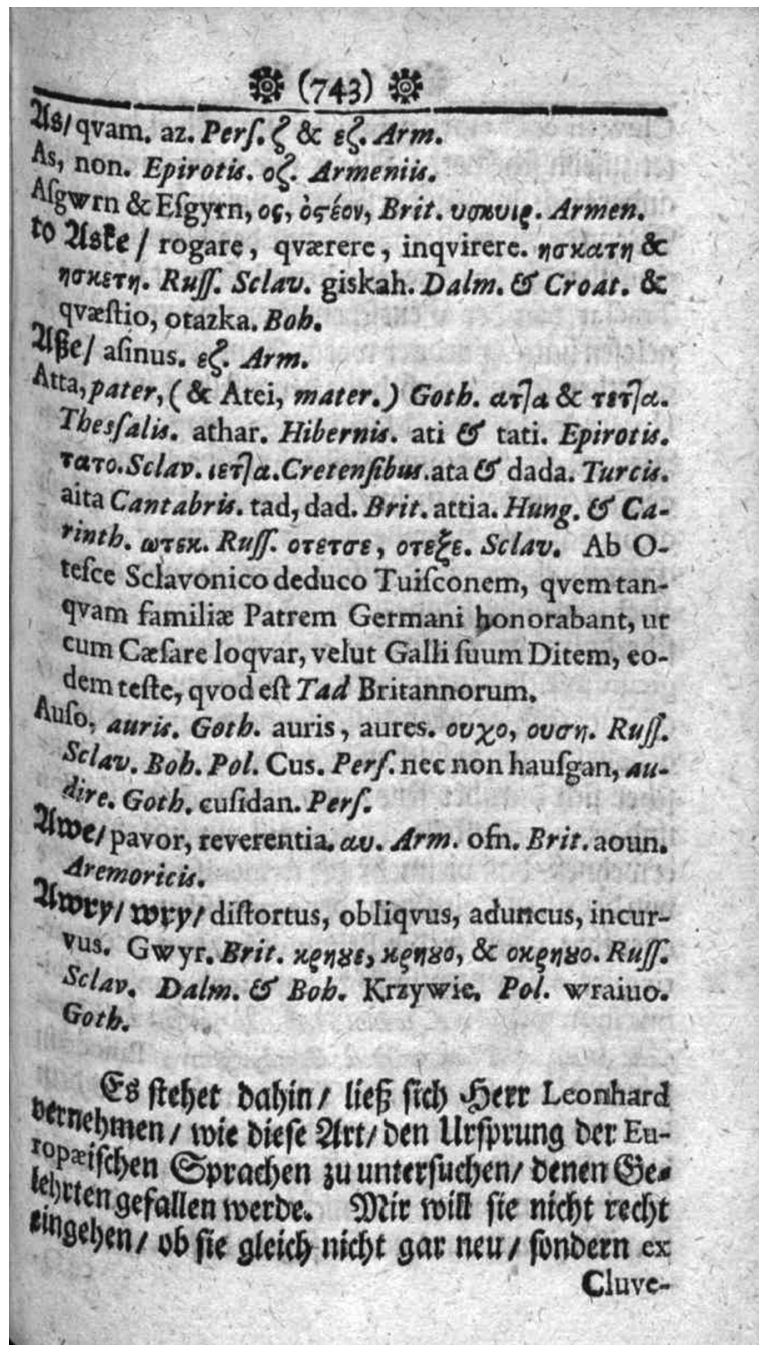

FIGURE 1. Tentzel's reproduction of Bernard's Etymologicon Britannicum, entries for the letter "A.” The Oxford University Press then lacking Russian and Armenian typescripts, those languages were rendered in Greek characters; Persian was given in Latin. Monatliche Unterredungen 3 (Sept. 1691): 743. Reproduced by permission, Staats- und Universität Bibliothek, Göttingen. 
Frankish) to be closely related to ancient Phrygian. ${ }^{14}$ Leonhard trotted out Herodotus's story of how the Phrygians were confirmed as the oldest nation, and Leonhard concluded that the Armenian language must have been descended from Phrygian, not vice versa. "Therefore the dialects of the ancient Germanic language, including not least the British, must not be derived from Armenian." 15 Tentzel's other fictitious character, "Antoni," agreed. Thus, although they disagreed with Bernard's particular thesis, the Etymologicon Britannicum sparked a wide-ranging discussion on the origin of language, linguistic affinity, and the relative ages of nations. Tentzel's interlocutors ultimately agreed that the coincidence of cognate terms in Germanic and Persian could probably be traced to a no-longer-extant parent/source language, probably Parthian and ultimately Scythian.

In October 1691 Leibniz read this exchange closely. He copied out in his own hand Bernard's Latin preface that Tentzel had reprinted. ${ }^{16}$ And he began making inquiries about borrowing the book itself. As luck would have it, just weeks before Leibniz found the discussion of Bernard's Etymologicon in Monatliche Unterredungen, he and Ludolf had exchanged letters.

Leibniz and Ludolf had initially met in person in 1688 when Leibniz was on his way to southern Germany and Italy in search of documentation for the Guelph genealogy. We catch a glimpse of their discussion in a letter Leibniz wrote while on the road, but then the correspondence went dormant while Leibniz was in Italy. ${ }^{17}$ In August 1691, just weeks before Leibniz found the discussion of Bernard in Tentzel's Monatliche Unterredungen, Ludolf reached out to Leibniz. In that initial 1688 meeting, Ludolf had asked Leibniz's advice about forming a Collegium Imperiale Historicum for the investigation of Germanic antiquities. In August 1691 when Ludolf travelled up to Gotha, he and his collaborators, Tentzel and Christian Franz Paullini (a physician in Eisenach with whom Leibniz had been in correspondence for a few months), formalized the by-laws of the Collegium, and again Ludolf sought the approval of Leibniz in his capacity as a lawyer. ${ }^{18}$

${ }^{14}$ Cf. Tentzel, Monatliche Unterredungen 2 (March 1690): 264.

15 Tentzel, Monatliche Unterredungen 3 (September 1691): 744.

${ }^{16}$ The extract he inserted between the leaves of A.I.7, \#185 Antonio Magliabechi to Leibniz, Florence, 22 September 1691. See also ed. note to A.I.7, \#221 Leibniz to Christian Franz Paullini, Hanover, 16/26 October 1691, p. 416n.

${ }^{17}$ A.I.5, \#121 Leibniz to Ludolf, Vienna, 30 August / 9 September 1688; A.I.5, \#126 Ludolf to Leibniz, Frankfurt, 14/24 September 1688; A.I.5, \#173 Leibniz to Ludolf, Vienna, 2/12 December 1688; A.I.5, \#208 Leibniz to Ludolf, Vienna, 10/20 January 1689.

${ }^{18}$ A.I.7, \#172 Ludolf to Leibniz, Gotha, 21/31 August 1691. For the Collegium Imperiale Historicum, see Franz Xaver von Wegele, Geschichte der Deutschen Historiographie seit dem Auftreten des Humanismus (Munich: Oldenbourg, 1885), 597-609. 
The by-laws looked fine to Leibniz. ${ }^{19}$ Beyond congratulations and encouragement, he had little of substance to say about them. Instead he seized the opportunity to start a discussion with Ludolf about his new project on Germanic languages and European origins. Note that when Leibniz wrote this reply in early September 1691, he had not yet seen either the July issue of Monatliche Unterredungen, where Tentzel had reprinted Bernard's letter to Ludolf, nor the September issue, where Tentzel and his friends "Leonhard" and "Antoni" discussed the substance of Bernard's Etymologicon Britannicum. Already at this early stage of his linguistic project Leibniz was perplexed about the relationships between languages. In a lexicon of the Britannic language printed as an appendix to Boxhorn's book on the Origin of the Gauls (just as Bernard's Etymologicon was printed as an appendix to Hickes's Anglo-Saxon grammar), Leibniz had noticed many affinities between Welsh and Germanic words. ${ }^{20}$ On the other hand, he noticed many words that showed no relation whatsoever. But maybe this was not surprising, given the transformations over time of the Germanic languages themselves. Glossaries of the Old Saxon and Frankish vocabularies differed "to high heaven" (toto coelo) from modern spoken German. In the same way, Codex Argenteus-in both its script and its idiom-was "enormously different" from both ancient Runic and modern Swedish. In fact, modern Swedish and Danish seemed to Leibniz to have more of AngloSaxon than of Ulfilas's Gothic. That languages changed over time was well understood. "If the first linguistic change between neighbors produces another dialect, the second and third change would in the end make another language," wrote Leibniz to Ludolf. Although the modern European languages had diverged over time, the ancient expressions of those languages, as preserved in ancient Greek and Roman texts, suggested that ultimately they flowed from a common source. The proof of a true affinity between these languages-however different they eventually may have becomewas the existence of languages that were radically different from those of

\footnotetext{
${ }^{19}$ A.I.7, \#181 Leibniz to Ludolf, Braunschweig, 5/15 September 1691. Cf. the readings of this discussion by Hans Aarsleff, "The Study and Use of Etymology in Leibniz," Studia Leibnitiana, Supplementa 3 (1969): 173-89; reprinted in Aarsleff, From Locke to Saussure: Essays on the Study of Language and Intellectual History (Minneapolis: University of Minnesota Press, 1982), 84-100; and John T. Waterman, Leibniz and Ludolf on Things Linguistic (Berkeley: University of California Press, 1978), 21-22.

${ }^{20}$ John Davies, "Antiquae Linguae Britannicae Lexicon Britannico-Latinum," in Boxhorn, Originum Gallicarum liber. See Prys Morgan, "Boxhorn, Leibniz and the Welsh," Studia Celtica 8/9 (1973-74): 220-28; and Morgan, "Boxhorn and the Welsh: Some Cambro-Dutch Contacts in the Seventeenth Century," Dutch Crossing 24 (2000): 183-90.
} 
ancient and modern Europe: Chinese and the languages of the Americas and Africa. That is to say, Leibniz was defining sets: the common origin of Euro-Asiatic languages, even if Chinese, African, American were entirely different.

As logistics went in the Republic of Letters, Leibniz's September letter to Ludolf missed its target. Leibniz had routed the letter through Friedrich Lucae at Kassel with instructions to forward it to Paullini at Eisenach, who would then send it to Tentzel at Gotha, where Ludolf had dated his letter two weeks earlier. Paullini later claimed that he had quickly sent Leibniz's letter to Tentzel, but by the time it arrived Ludolf had departed on a side trip to Erfurt (Ludolf had been born and raised there). Evidently Tentzel had tossed Leibniz's letter in a corner and forgotten about it when Ludolf returned. ${ }^{21}$ When he noticed his error a few weeks later, Tentzel forwarded Leibniz's letter again, this time to Ludolf's home in Frankfurt, where it finally arrived more than a month after Leibniz had written it. ${ }^{22}$ Ludolf didn't respond.

Thus, in October 1691 when Leibniz found the Monatliche Unterredungen discussion of Bernard, he was well positioned to inquire about the volume from this little group of scholars. Hoping that Ludolf was still at Gotha (by late October 1691 Ludolf was long gone), Leibniz asked Paullini to intercede with a request to borrow the Bernard volume. ${ }^{23}$ Paullini passed Leibniz's request on to Tentzel and also to Ludolf directly. ${ }^{24}$

Tentzel passed Leibniz's request on to Ludolf too. Writing to Leibniz for the first time ("I have been watching you for a long time, and I consider you among the outstanding ornaments of Germany"), Tentzel explained that Ludolf's copy of Bernard's Etymologicon Britannicum was the only one he knew of in all of northern Germany. Maybe the Acta Eruditorum had a copy at Leipzig. In any case, the volume was not Tentzel's to give; but surely with a single word, Ludolf would share his copy with Leibniz. ${ }^{25}$

Immediately upon receiving this news and learning that his September letter had misfired, Leibniz wrote again to Ludolf. "I would like to see the most learned Englishman Ed. Bernard's meditations on the origins of the European languages, as indicated in the German Monatliche

\footnotetext{
${ }^{21}$ A.I.7, \#239 Paullini to Leibniz, Eisenach, 20/30 November 1691.

${ }^{22}$ A.I.7, \#181 Leibniz to Ludolf, Braunschweig, 5/15 September 1691, ed. note.

${ }^{23}$ A.I.7, \#221 Leibniz to Paullini, Hanover, 16/26 October and postscriptum 26 October / 5 November 1691.

${ }^{24}$ A.I.7, \#239 Paullini to Leibniz, Eisenach, 20/30 November 1691; see ed. note for Paullini's letters to Tentzel and to Ludolf.

${ }^{25}$ A.I.7, \#244 Tentzel to Leibniz, Gotha, 24 November / 4 December 1691.
} 
Unterredungen," Leibniz stated bluntly. ${ }^{26}$ "If only Learned men would take such scholarship upon themselves, for in no other way can the origins of the most ancient peoples better be learned." Unfortunately he then buried the request for Bernard under two other languages evidently not related to Germanic: Hungarian, both in Transylvania and beyond the Caspian Sea; and Basque. Of Bernard's hypothesis about the relationship between Germanic and Slavic, as explained to Ludolf in the December of 1690 letter that Tentzel had published, "I don't know whether he hit the nail on the head," Leibniz wrote. He repeated what he had written in September about John Davies's lexicon reprinted in Boxhorn, that the "Britannic" language did share many words with Germanic and Latin, but after so many mutations over time there were even more words of unknown origin. And although there was a Slavic-speaking region in Lower Saxony itself (the Wendland), it seemed to be a colony that had migrated from the eastern Baltic and that had not thoroughly assimilated with the local German. "If there is anyone in Germany, to say nothing of Europe, who could bring light to linguistic matters, I reckon it would be you," he wrote to Ludolf. "Since this inquiry into the origins of the Germanic nation is of greatest moment, I would like to know your sense of those things illustrating the earliest antiquities of our nation [gens]."

With so many linguistic topics going on in the second half of the letter, it is little wonder that Ludolf made no mention of Bernard's Etymologicon Britannicum when he responded to Leibniz in January of 1692. Ludolf filled more than a sheet and a half of quarto-sized paper, six pages when folded, on linguistic topics ranging from relationships between Semitic languages, the unrelatedness of Hottentot and other African languages, and a long couple of paragraphs on the kinship of Germanic, Latin, and the Nordic languages. It was an entertaining letter written with wit and verve: at one point Ludolf called himself a troublemaker and quipped, "it's not as if they didn't have noses and aures Obren or oculos Oogen before they learned Latin." ${ }^{27}$ Still, Ludolf's discourse raised more questions for Leibniz than it answered. Ludolf's speculation about an ancient common language, "(which if you wish to call it Japhetic I will not be opposed)," from which flowed cognate terms in Greek, Latin, and Germanic, only made Leibniz more curious to see Bernard's work that supposedly proved that that ancient Japhetic proto-language was Slavic.

In April 1692 Leibniz tried again. "What is your judgment about Bernard's thoughts concerning the origins of the British language?" he wrote.

${ }^{26}$ A.I.7, \#247 Leibniz to Ludolf, Hanover, 26 November / 6 December 1691.

${ }^{27}$ A.I.7, \#315 Ludolf to Leibniz, Frankfurt, 25 January / 4 February 1692. 
"I admit that it would not be unprofitable to compare Slavonic, Germanic, and Armorican, and I would add also Estonian. I discovered that the Wends of Lüneburg have something of Estonian mixed in there. Does a commerce of letters continue between you and Bernard? In that man there is certainly a rare and broad erudition." ${ }^{28}$ But again Leibniz inserted his Bernard inquiry only at the end of a lengthy discussion of languages. Thus in July 1692 when Ludolf wrote a point-by-point reply, by the time he reached Leibniz's discussion of Bernard, Ludolf was out of space. "Just recently I received a letter from Bernard in Oxford," Ludolf wrote. "His Josephus has been returned to him for illustrating. But more soon. The page is now full. Vale." ${ }^{29}$

Thus after nearly a year, from the fall of 1691 to the summer of 1692 , despite repeated polite attempts to induce Ludolf into offering to send up his copy of Bernard, Leibniz still had nothing.

\section{HENRI JUSTEL IN LONDON}

Hiob Ludolf was by no means Leibniz's only interlocutor on linguistic topics. Over the second half of 1691 and the first half of 1692 Leibniz's understanding of the relationships between languages advanced considerably, thanks particularly to a substantial exchange of letters with Adam Kochanski at Warsaw. And Leibniz maintained letter exchanges with other wings of his correspondence network also, including in England.

Ever since his extended stay at Paris, 1672-76, Leibniz had maintained a correspondence with the Huguenot robin Henri Justel (1620-93). Leibniz and Justel had enjoyed a rapid letter exchange in the late 1670s. They had largely fallen out of touch through the 1680s when Justel (having advance knowledge that toleration of the Huguenots would be revoked) took a position in England. But in 1690, Leibniz having returned from his Italian tour, the correspondence resumed. As keeper of the royal manuscripts at St. James Palace in London, Justel was well positioned to procure medieval documents Leibniz wanted for the Guelph history. ${ }^{30}$ As a member of the

\footnotetext{
${ }^{28}$ A.I.8, \#127 Leibniz to Ludolf, Hanover, 18/28 April 1692.

${ }^{29}$ A.I.8, \#185 Ludolf to Leibniz, Frankfurt, 14 / 24 June 1692. See Thomas Roebuck,

" 'Great Expectation Among the Learned': Edward Bernard's Josephus in Restoration Oxford," International Journal for the Classical Tradition 23 (2016): 307-25.

${ }^{30}$ Philippe Dally, "Les Justel, II. Henri Justel (1620-1693)," Bulletin de la Société de l'Histoire du Protestantisme Français 79 (1930): 31; Harcourt Brown, "Un cosmopolite du grand siècle," Bulletin de la Société de l'Histoire du Protestantisme Français 82 (1933): 199.
} 
Royal Society, Justel kept Leibniz informed of scholarly doings in and around London. Justel even had long known George Hickes, author of the Anglo-Saxon and Gothic grammar to which Bernard's Etymologicon was appended. It wasn't from Ludolf that Leibniz got his copy of Bernard's work. It came from Henri Justel.

In a run-down of personnel changes in the Royal Society, Justel mentioned that "A Scot named Mr. Gregory has taken the place of Mr. Bernard. He is a capable young man and a good geometrician." ${ }^{31}$ Leibniz took this ambiguous statement (which included no indication that Justel had shifted from news of London to news of Oxford) to mean that Bernard had passed away. "I hope that Mr. Bernard is not dead," Leibniz inquired in May. ${ }^{32}$ "This would be a great loss. Maybe he has changed profession," as indeed was the case, Bernard having resigned the Savilian Chair but otherwise being alive and well. In the Akademie Ausgabe of Leibniz's Sämtliche Schriften und Briefe there is no indication that Justel enclosed the volume with that letter, nor is there any acknowledgement of its receipt in Leibniz's response. But a week later Leibniz passed on to Antonio Magliabechi Justel's news, and he mentioned also that he had a specimen of the Etymologicon Britannicum. ${ }^{33}$

Immediately Leibniz put Bernard's Etymologicon Britannicum to use. In May 1692 Leibniz asked Justel's advice about some obscurantist heraldry on a seal from around 1200 sent from King John of England to the Guelph Holy Roman Emperor Otto IV. ${ }^{34}$ On the seal that accompanied the diploma, one side depicted John as king seated regally on a throne, while the other side depicted John as duke of Normandy and Aquitaine and count of Anjou mounted on a horse and raising a sword. The ducal/comital side bore a coat of arms emblazoned with three lions. Leibniz guessed that the lions pertained to the Continental territories and were later applied to the English crown. Or were they not lions at all but leopards? Did lions represent royal authority and leopards merely John's ducal or comital holdings? The symbolism seemed grandiose to the point of silliness. In fact, so did the whole enterprise of heraldry (Justel would later respond that the leopards "were badly made lions"). On a whim, Leibniz took a side track to the term "heraldry" itself, that is to say "to emblazon." Leibniz had found that

\footnotetext{
${ }^{31}$ A.I.7, \#350 Henri Justel to Leibniz, [London], 25 March 1692. David Gregory succeeded Bernard as Savilian Professor of Astronomy, 1691-1708.

${ }^{32}$ A.I.8, \#162 Leibniz to Justel, [Hanover], 24 May / 3 June 1692.

${ }^{33}$ A.I.8, \#169 Leibniz to Magliabechi, Hanover, 1/11 June 1692.

34 "Pactum cum Iohanne Rege Angliae," 8 September 1202, in Monumenta Germaniae Historica, Constitutiones 2 (1896), no. 25, pp. 29-30.
} 
already in antiquity both Celts and Saxons used the term blason or blässe to signify a mark; in Lower Saxony white marks on the brows of horses were still called blässen (cf. English, blaze). In French blesser meant to wound, but "originally it signified to mark, or as was still said in German einen zeichnen, signare or marquer, that is to say to give him some blows that leave a mark." Furthermore in English blessed meant benedictus, "which in German is gesegnet, that is to say signatus, signed with the sign of the cross," just as in the Loire region of France seigner still meant to make the sign of the cross. It was Paul Pellisson-Fontanier, the Huguenot convert to Catholicism in Paris, who had sparked this inquiry, and to Justel, the Huguenot refugee in London, Leibniz sent this little conjecture in May. ${ }^{35}$

But then something interesting happened. Now that he had Bernard's Etymologicon, in addition to the cognates he had already identified in Celtic and French, Old and New Low German, as well as Latin, he added Slavic cognates as well. In Bernard's Etymologicon Britannicum under the $B$ 's (Leibniz already knew the A's, as reprinted by Tentzel), Leibniz looked up the term Blessed, beatus, benedictus: blaxen in Dalmatian, blazeny in Bohemian. "In effect, it seems that nearly all languages are often nothing but well muddled variations from the same roots." ${ }^{36} \mathrm{~A}$ few days later Leibniz formalized his etymological conjecture and sent it to Claude Nicaise for publication in the Journal des Sçavans, where he exhorted his fellow scholars to collect the particular words not only of the major languages of Europe but of their local dialects too.

\section{CONNECTING WITH EDWARD BERNARD}

In a sense, Leibniz's initial objective was fulfilled: He had Bernard's Etymologicon Britannicum, or at least enough of it to see Bernard's evidence of the affinity between Slavic and British. But as was typical of Leibniz, the more evidence he got from friends who were trying to be helpful, the more questions their evidence raised in his mind. What started as a wish for Edward Bernard's book turned into a wish for Edward Bernard himself. In November 1692, an opportunity to fulfill that wish came through.

By now it was a year after Leibniz had written to Ludolf directly about

${ }^{35}$ A.I.8, \#162 Leibniz to Justel, [Hanover], 24 May / 3 June 1692. See the ed. note at A.I.8, \#89 Leibniz to Paul Pellisson-Fontanier, Hanover, 13 July 1692.

${ }^{36}$ A.II.2, \#153 Leibniz to Claude Nicaise, Hanover, 5 June 1692. "Conjecture de M. Leibnis sur l'origine du mot Blason,” Journal des Sçavans (28 July 1692): 345-47. 
borrowing the book. Johann Theodor Heinson (ca. 1669-1726), a Hanoverian courtier who had travelled to the Netherlands and England to meet the community of scholars and to study Oriental languages, wrote to Leibniz out of the blue. "Most honoured Sir, These few lines will excuse myself of the boldness i committ thereby, as they beare the execution of Your wellcome Orders, Your Honour granted me at my depart." ${ }^{37}$ This line presents the opportunity to explain why a year earlier Leibniz didn't simply write to Bernard directly. In the Republic of Letters it was the recipient who performed the favor of reading a letter. The debtor in the relationship was the author, who imposed the burden of reading it. (In the case of Heinson trying out his newly acquired English, the burden certainly was on the reader!) One did not simply randomly send a letter without some prior basis for doing so. The basis for Heinson's letter was a set of oral instructions that Leibniz had given him at Hanover before departure, and the letter fulfilled those instructions by offering a run-down of goings on among the learned in London. Although the prohibitive price had prevented Heinson from purchasing the Transactions of the Royal Society as Leibniz had requested, Heinson did offer news of recent deaths and departures, the Royal Society's desire of having a copy of Leibniz's "De combinatione," and of so many new books that it was better to procure a catalog than to try to purchase all of them. "This nation inclines to writing very hard, so that scarce a learned man in England i spoke, who had not publish'd some thing, or, at least was thereabout."

Heinson's letter also contained a bonus-an invitation to write to Bernard directly. In talking up Leibniz at the Royal Society, Heinson met the mathematicians with whom Leibniz had formerly corresponded but long since fallen out of touch. "Dr. Bernard, who presents his service to You, wrote many things, and is still for some news," Heinson explained. "Dr. Newton in Cambridge complaints deeply of the loss of Your correspondence he had 18 years ago." Thus on good authority Leibniz had confirmation that Bernard was "still for some news," and perhaps, like Newton, might "complaint deeply" about the loss of correspondence. A few weeks later Leibniz approached Bernard directly.

In breaking the ice, Leibniz was careful to point out that it was at Bernard's invitation, as relayed through Heinson, that Leibniz wrote. Leibniz also named Justel as a mutual acquaintance, and through Justel Leibniz was aware of the status of Bernard's Josephus edition. ${ }^{38}$ Leibniz continued

${ }^{37}$ A.I.8, \#346 Johann Theodor Heinson to Leibniz, London, 25 November / 5 December 1692.

${ }^{38}$ Thomas Smith, Vita . . Edwardi Bernardi (1704), 34-42. See Thomas Roebuck,

“'Great Expectation Among the Learned,'” 307-25. 
to drop names throughout his letter, seeking to bring Bernard into his growing network and his polymathic interests: Grimaldi on languages and China, Kochanski on languages and Poland, Simon de La Loubère on mathematics and Siam, Cassini the geographer, Nicolas Toinard the antiquarian, Jean Harduin the numismatist, and Ezechiel Spanheim, who had palimpsest annotations in his copy of Josephus. ${ }^{39}$ Leibniz did not mention Hiob Ludolf, through whom he had a second report of Bernard's Josephus project. Actually, Leibniz was not impressed by the Josephus. "I would hope that it might be done without prejudice to the rest of your excellent work," he admonished disapprovingly. By "your excellent work" specifically he meant a commentary to annotate a table of alphabets that Bernard had published at the same time as the Etymologicon Britannicum. Leibniz considered Bernard's linguistic avocation to be of much greater moment. "I believe there is no means more suited for knowing the relations of nations, remote beyond the memory of History, than the traces of their origins that exist in languages." 40

But Bernard was having none of it. Replying in June, Bernard opened his letter with high praise for Leibniz's accomplishments at the pinnacle of mathematics, "the arranging of analogies to a perfection and neatness every bit the equal of Huygens, Barrow, Wallis, and a few others; beyond which it is not possible to ascend further with any ease." ${ }^{41}$ But what was this business about medieval charters that Leibniz was working on now? An enormous project, and enormously distracting. Bernard was referring to the Codex diplomaticus iuris gentium. Leibniz would later clarify that the project was not so enormous, a first volume of unpublished monuments from 1100 to 1500 with a second and a third to appear later. ${ }^{42}$ (Though in fact Bernard was correct, as the projected second and third volumes never were completed.) Bernard supposed that in any case a compendium on law would sell well. "Truly proceed, most learned and broad-minded sir, and may you earn as much merit among moderate ones of the Republic of Letters as you have among mathematicians." ${ }^{33}$

Each pitched their new projects of which the other disapproved. Bernard wondered whether the Wolfenbüttel library had a version of an oration by Rufinus on Josephus's discussion of Maccabees. Leibniz didn't

\footnotetext{
${ }^{39}$ On the rhetorical device of name dropping, see Françoise Waquet, "Qu'est-ce que la République des Lettres? Essai de sémantique historique," Bibliothèque de l'École des Chartes 147 (1989): 473-502.

${ }^{40}$ A.I.9, \#198 Leibniz to Bernard, Hanover, 7/17 March 1693.

${ }^{41}$ A.I.9, \#305 Bernard to Leibniz, Oxford, 1/11 June 1693.

42 A.I.10, \#104 Leibniz to Bernard, Hanover, 27 December 1693 / 6 January 1694.

${ }^{43}$ A.I.9, \#305 Bernard to Leibniz, Oxford, 1/11 June 1693.
} 
respond. Bernard wondered what titles the Wolfenbüttel library held on geography or chronology, whether Latin, Greek, or Arabic. Leibniz suggested that Bernard's own libraries had better collections of geography than anything in Germany. Bernard asked Heinson to inquire about a Russian bible or lexicon or a particular Polish lexicon. Leibniz volunteered that he had a Georgian dictionary that indicated some cognates with Greek as well as a few in Slavonic and Germanic, though most of the language seemed very different. For his part, Leibniz tried to engage Bernard's Josephus project on the level of Herodean coins, but Bernard opted not to pursue a discussion of numismatics in his response. Leibniz tried again in his second letter, but Bernard didn't respond at all.

But most of their exchange addressed language. At least so it was from Leibniz's side. He asked far more questions than he received answers. How much, exactly, had Edward Bernard discovered about the Asiatic origins of the European nations? Clearly Germanic, Britannic, and Slavic shared many points in common. If more were known of the languages of "Scythia," then the precise relationship between the European languages would appear and the connection between Germanic and Persian would be less of a mystery. ${ }^{44}$

As he had proposed to Ludolf a year before, Leibniz was trying to establish sets: those European languages that shared a common origin (Germanic, Slavic, Celtic, Greek, as well as Persian and possibly, on Bernard's evidence, Georgian and Armenian); and others who had settled in Europe but were of different origin (Basque, Etruscan, Epirotic). Leibniz was hoping Bernard would confirm this working hypothesis. Bernard's Etymologicon Britannicum was evidence of the first set-the British language sharing cognates with Slavic, Armenian, and Persian.

Leibniz must have been disappointed to discover that Bernard's Etymologicon Britannicum lacked an entry for the term "Mare." Or perhaps he saw it as an opportunity to contribute to Bernard's project. At the beginning of 1692, Adam Kochanski, the Jesuit mathematician at the court of Poland, had described to Leibniz an audience between King Jan III Sobieski and the Jesuit Philippe Grimaldi who passed through Poland on his way to Muscovy and China. In comparing the Lipka Tartars of Lithuania and the Oriental Tartars of China, the king and the missionary had discovered a few cognate terms common to both the eastern and western Tartars. One such term was Morak or Moran, signifying a horse..$^{45}$ Leibniz was very

${ }^{44}$ A.I.9, \#198 Leibniz to Bernard, Hanover, 7/17 March 1693.

${ }^{45}$ A.I.7, \#295 Adam Adamandus Kochanski to Leibniz, Warsaw, 8/18 January 1692. 
much taken by this coincidence, and he added to it some additional evidence of his own. The ancient Gauls of Brittany and Wales used the term Mar or Mare to signify a horse. When he wrote to Bernard in March of 1693 Leibniz condensed the peripatetic means by which he found this cognate term but he commented, "The Jesuit Grimaldi, as he was about to return to China four years ago, told me at Rome that even in the region of Chinese Tartary mara is horse, which used to be a Celtic word and now is British and German, and it extends from the Far East all the way to the Western Ocean." ${ }^{46}$ Bernard was not surprised to learn that. "No wonder Oriental Tartars and Parthians, Iberos, Armenians have a common vocabulary with Saxons and Germans and Britons; since it is certain that both the nations and the languages of Europe migrated together from Persia, Scythia, Armenia, through Asia Minor and the Black Sea to the West." ${ }^{47}$

On a more local and specific level, Leibniz asked Bernard "whether the Goths and the Getes are the same; then whether the Cimmarii were the same thing as the Cimbrii." ${ }^{48}$ Classical geographers (Pliny, Strabo) and late antique historians described a Gete nation living on the western shore of the Black Sea and up the Danube, precisely the region through which Leibniz imagined a Germanic migration from Scythia to Europe. The Getes disappeared from history about the time the Goths showed up, and, based on the combination of consonants and vowels (Gotes/Getes) plus the overlap in historical time and geographic space, many scholars-although not unanimously - had conflated them as two terms for the same entity. Jordanes's history of the Goths, for example, was entitled Getica.

So too the Cimmarii, attested in one age on the eastern shore of the Black Sea, while the Cimbri were encountered by the Romans in the first century BC in northern Europe, and the Latin name for Wales was Cambria. Leibniz wondered specifically, "Whether you would agree that the European nations came from the East but retreated to the North; I believe that first the Celts, then the Cimmerians, later the Germans to the coast of the Ocean at the mouths of the Rhine, Elbe and Weser; related nations, and initially with similar languages." ${ }^{49}$ And just as the Anglo-Saxons were attested in the historical period as having migrated from the Continent to Britain, might the same be inferred about the Cimbri (from Jutland) and the Cymri or Cambri (of Wales)? Modern archeologists reject these early modern conflations, and even Bernard was not willing to split hairs: "The

${ }^{46}$ A.I.9, \#198 Leibniz to Bernard, Hanover, 7/17 March 1693.

${ }^{47}$ A.I.9, \#305 Bernard to Leibniz, Oxford, 1/11 June 1693.

${ }^{48}$ A.I.9, \#198 Leibniz to Bernard, Hanover, 7/17 March 1693.

${ }^{49}$ A.I.9, \#198 Leibniz to Bernard, Hanover, 7/17 March 1693. 
Britannic language however came to this island from Gaul. Cimmerians and Getes, as well as the Goths, were settled formerly at the Black Sea. There, overcome by people from the Orient and even by the Roman armies, they were expelled into the North of Europe. Jordanes is not to be overly trusted in these things." ${ }^{50}$ But in his effort to legitimize the Low Saxons and their origins as Scythian and not Gothic/Swedish, Leibniz required more precision in the relations of nations and their prehistoric migrations than Bernard, who was washing his hands of one project in order to focus on others.

Of the British Isles specifically, Bernard was somewhat less reticent. Leibniz (seeking to colonize Britannia with his Low Saxons) asked Bernard's judgment, "Concerning Scots, it is a wonder to me that a great part of Scotland was populated originally by Saxons, as indicated by language, although it does not appear in Bede nor anyone else when the Saxons crossed to Scotland. Whether therefore those are an older colony of Saxons, especially since the Scots language, as I understand it, has retained here and there something of Saxon origin? Or shall we say those more recent migrations were not observed by writers in Scottish History? Or is there something that I have missed?" ${ }^{1}$ Here Leibniz and Bernard talked past each other. By "Scots," Leibniz meant primarily the language; although secondarily he also referred to the people who spoke it. Bernard limited his answer to the people; but these he divided into two sets, ancient and modern: "The Scots finally remembered by ancient writers are none other than the Irish nation. Of those who are now called Scots, the inhabitants of northern Britain, some migrated from Hibernia, while some departed from Anglia. Be well, excellent sir. I expect frequent letters and these quickly through the general Post, as they say." ${ }_{52}$

Leibniz wasn't buying Bernard's pat answers. In the third letter (December 1693 / January 1694) he pressed Bernard on the relationship between Gallo-Celtic and Germanic. "The Britannic language came to this island from Gaul," was Bernard's answer on the subject. That begged the question, how did it reach Gaul in the first place? "Your Britannic language, which is the same as Armorican," Leibniz protested, "I found to be manifestly Semi-Germanic." The same could also be said of ancient Gallic, or at any rate the languages of the ancient Germans and Gauls were close. "Some of the Britons come from Armorica, I concede as yours also confirm," he

\footnotetext{
${ }^{50}$ A.I.9, \#305 Bernard to Leibniz, Oxford, 1/11 June 1693.

${ }^{51}$ A.I.9, \#198 Leibniz to Bernard, Hanover, 7/17 March 1693, pp. 330-31.

${ }^{52}$ A.I.9, \#305 Bernard to Leibniz, Oxford, 1/11 June 1693.
} 
admitted. "But there was a partial remnant from those who remained on the opposite coast, that is the Germanic." Leibniz suspected that the ancient inhabitants then on the Germanic coast were not yet strongly differentiated in the way that the present nations and languages were. ${ }^{53}$

In the same way, Bernard's assertion about the ancient Scots being Irish also raised a question. If the Scots came from the Irish, "then where did the Irish come from?" Leibniz wondered. "And what of their language?" Comparing Lord's Prayers in Irish and Welsh, Leibniz found those two supposedly Celtic languages to be far apart. On the other hand John Wallis, the Oxford geometrician who had published a grammar of the English language, explained in a preface ad lectorem that Welsh and Cornish, as well as Irish and highland Scottish, differed from each other only slightly. ${ }^{54}$ Leibniz politely deferred to Wallis's judgment, "But You," he invited Bernard, "who have treated this very carefully, will have stated it the best." And speaking of Scottish again, what ever became of the Picts?

\section{CONCLUSION}

Given his interest in the relations of ancient and modern languages as well as the empirical data that he had assembled in the course of his scholarship, Bernard could have become a very useful informant for Leibniz's inquiry into the origins and migrations of nations. But Bernard did not respond. Leibniz's letter was not so long in terms of pages filled, but the depth of his questions, fired scattershot and one after another, made for daunting reading. Of Leibniz's first letter, the one to which Bernard did respond, even a librarian at the Bodleian acknowledged on a catalog card, "There is much intricate detail in this letter, which moreover is in a difficult handwriting." ${ }_{55}$

Using social network analysis it would be possible to graph the three clusters described here: Leibniz and Bernard, Justel and (possibly) PellissonFontanier, and the Tentzel-Ludolf circle. Such a graph could be organized

${ }^{53}$ A.I.10, \#104 Leibniz to Bernard, Hanover, 27 December 1693 / 6 January 1694. Cf. A.I.8, \#207 to Kochanski [Hanover, July 1692].

${ }^{54}$ A.I.10, \#104 Leibniz to Bernard, Hanover, 27 December 1693 / 6 January 1694. Cf. A.I.10, \#411 Leibniz to Thomas Smith, Hanover, 14/24 October 1694. See Considine, Small Dictionaries and Curiosity, 123-24.

${ }^{55}$ MS Smith 5 fols., 143-46, (Hanover, 7/17 March 1683 [sic: should read 1693]), Index of Literary Correspondence, Selden End, Bodleian Library, digitized by the Cultures of Knowledge Project, http://emlo.bodleian.ox.ac.uk. The comment is likely by Colin Bertram Hunt. See Miranda Lewis, "Ghosts in the Machine: (Re)Constructing the Bodleian's Index of Literary Correspondence, 1927-1963," Cultures of Knowledge, 26 April 2013, http://www.culturesofknowledge.org/?p $=295$. 
geographically, hierarchically with significance factors assigned to the human actors, to the topics raised in the letters, or with weighted vectors indicating the flow of communication. ${ }^{56}$ But the graph would also have to account for the circuitous pathways by which those connections were actually made. April Shelford described "gatekeepers" who mediated PierreDaniel Huet's access to scholars beyond his immediate reach. ${ }^{57}$ The case study presented here shows precisely how Leibniz's gatekeepers (actors with whom he had a direct association) mediated his access to an actor beyond his reach: Leibniz's letter to Ludolf routed through Friedrich Lucae, Paullini, and Tentzel (and Tentzel again) before finally reaching Ludolf not at Gotha but in Frankfurt; or the pathway to Bernard opened not through Ludolf as Leibniz expected nor even through Justel but through Heinson in London.

A graphic chart would also suggest a permanence or durability to an association that in fact was ephemeral-in the case of direct association between Leibniz and Bernard, limited to the year 1693. Leibniz's links to both Justel and Pellisson-Fontanier were terminated in 1693, too, with the deaths of both of those actors. "Networks rendered contingent on people's interactions turn out to have a fragile temporality," wrote social anthropologist Marilyn Strathern. "They do not last for ever; on the contrary, the question becomes how they are sustained and made durable." ${ }^{58}$ Carol Pal describes a circle of a half dozen female scholars with a life span of about four decades before that particular configuration was disrupted..$^{59}$ The community existed only so long as the participants engaged in their literary dance. In the case here, the nagging earnestness of one party (Leibniz) was not sufficient to compel the other party (Bernard) to respond.

To send a letter was not to do the recipient a favor. ${ }^{60}$ On the contrary, it

\footnotetext{
${ }^{56}$ Dan Edelstein, "Intellectual History and Digital Humanities," Modern Intellectual History 13 (2016): 237-46; Edelstein et al., "Historical Research in a Digital Age: Reflections from the Mapping the Republic of Letters Project," American Historical Review 122 (2017): 400-24. Also Reassembling the Republic of Letters, http://www.Republic OfLetters.net; Nora Gädeke and Lothar Krempel, "Korrespondenten-Territorien," Die Leibniz-Connection, https://leibniz.uni-goettingen.de/visualization/territories.

${ }^{57}$ April G. Shelford, Transforming the Republic of Letters: Pierre-Daniel Huet and European Intellectual Life, 1650-1720 (Rochester, NY: University of Rochester Press, 2007), 33.

${ }^{58}$ Marilyn Strathern, "Cutting the Network," Journal of the Royal Anthropological Institute 2 (1996): 517-35, at 523.

${ }^{59}$ Carol Pal, Republic of Women: Rethinking the Republic of Letters in the Seventeenth Century (New York: Cambridge University Press, 2013).

${ }^{60}$ Anne Goldgar, Impolite Learning: Conduct and Community in the Republic of Letters, 1680-1750 (New Haven, CT: Yale University Press, 1995), 25-29.
} 
obliged the recipient to act. Françoise Waquet explained that, letters being essential to the very existence of the Republic of Letters, "every letter implied a response, every gift a gift in return. Not to fulfill these duties was to disrupt the dynamic, to condemn oneself in the end to being marginalized." ${ }^{11}$ Sometimes the initial request-whether for a material item or simply for knowledge-went unfulfilled. Ludolf never did send Bernard's Etymologicon Britannicum, but much more valuable to Leibniz than this single item was the correspondence with Ludolf that endured for years. Ulrich Schneider once commented that it is astonishing to see how often Leibniz formulated philosophical insights purely as material for the exchange of ideas. ${ }^{62}$ Martin Mulsow has described the serendipity that governed the exchange of knowledge in the Republic of Letters: the chance discovery of an ancient fragment, whether coin, inscription, or text; the chance relaying of a fragment to a scholar who found a way to use it; the chance preservation of a scholar's records, notes, or letters that offers us in the twenty-first century a window into the world of three hundred years ago. ${ }^{63}$ Indeed, it is only due to the excellent work of Berlin-Brandenburg Academy of Science—ongoing for nearly a century-that we have the Leibniz correspondence published in chronological order, so that we can see the course of his inquiries into historical linguistics in search of the origins of the nations of Europe. As the Bodleian librarian acknowledged, it is only in the intricate detail of their correspondence that we can see how this story unfolded and how relationships were built, structured, and terminated in this one little corner of the international Republic of Letters.

Old Dominion University.

\footnotetext{
${ }^{61}$ Waquet, "Qu'est-ce que la République des Lettres?,” 493.

${ }^{62}$ Ulrich Johannes Schneider, "Leibniz und Lessing als Bürger der Gelehrtenrepublic," in Kultur der Kommunikation: Die europäische Gelehrtenrepublik im Zeitalter von Leibniz und Lessing, ed. Schneider (Wiesbaden: Harrassowitz, 2005), 345-56. Cf. Goldgar, Impolite Learning, 227.

${ }^{63}$ Martin Mulsow, Präkares Wissen: Eine andere Ideengeschichte der Frühen Neuzeit (Berlin: Suhrkamp, 2012).
} 